\title{
Control of Chlorinated Volatile Pollutants at Indoor Air Levels Using Polymer-based Photocatalyst Composite
}

\author{
Byeong-Chan Kim, Hye-Jin Kim, Ji-Eun Kim, Eun-Ju Park, Ji-Sun Noh \\ Hyun-Jung Kang, Seung-Ho Shin, and Wan-Kuen Jo* \\ Department of Environmental Engineering, Kyungpook National University \\ 80 Daehak-ro, Buk-gu, Daegu 702-701, Korea
}

(Received for review January 17, 2013; Revision received March 12, 2013; Accepted March 13, 2013)

\section{요 약}

폴리아닐린 기반 이산화티타늄 복합체(폴리아닐린-이산화티타늄 복합체)를 다른 소성온도 조건에서 제조하여 일반 공기 질 수준의 트리클로로에틸렌과 테트라클로로에틸렌에 대한 제어 적용성 연구를 수행하였다. 모든 조사대상 오염물질에 대 하여 폴리아닐린-이산화티타늄 복합체의 제어효율은 제조 시 적용된 소성온도 변화에도 아무런 경향을 나타내지 않았다. 대신에, 소성온도를 $350{ }^{\circ} \mathrm{C}$ 에서 $450{ }^{\circ} \mathrm{C}$ 로 증가시켰을 때 3 시간의 광촉매 공정 동안에 폴리아닐린-이산화티타늄 복합체의 제어효율은 트리클로로에틸렌과 테트라클로로에틸렌에 대하여 $61 \%$ 에서 $72 \%$ 로, $21 \%$ 에서 $39 \%$ 로 각각 증가하였다. 그러 나, 소성온도를 $450{ }^{\circ} \mathrm{C}$ 에서 $550{ }^{\circ} \mathrm{C}$ 와 $650{ }^{\circ} \mathrm{C}$ 로 더 증가시켰을 경우에는 폴리아닐린-이산화티타늄 복합체에 의한 트리클로로 에틸렌과 테트라클로로에틸렌의 제어효율이 점진적으로 감소하였다. 이러한 결과는 폴리아닐린-이산화티타늄 복합체 내 아나타제 결정상의 생성량과 입자의 비표면적 변화 때문으로 판단되었고, 이러한 특성 변화는 X-선 회절과 주사전자현미경 분석결과를 통하여 확인하였다. 가장 낮은 주입농도 $(0.1 \mathrm{ppm})$ 조건에서 트리클로로에틸렌과 테트라클로로에틸렌의 평균 제 어효율은 각각 $72 \%$ 와 $39 \%$ 이었고, 반면에 가장 높은 주입농도 $(1.0 \mathrm{ppm})$ 조건에서는 트리클로로에틸렌과 테트라클로로에틸 렌의 평균 제어효율은 각각 $52 \%$ 와 $18 \%$ 로 나타났다. 공급 유량을 $0.1 \mathrm{~L} \mathrm{~min}^{-1}$ 에서 $1.0 \mathrm{~L} \mathrm{~min}^{-1}$ 로 증가시켰을 때 트리클로로에 틸렌과 테트라클로로에틸렌의 평균 제어효율이 각각 약 $100 \%$ 에서 $47 \%$ 그리고 약 $100 \%$ 에서 $18 \%$ 로 감소하였다. 또한, 상대 습도를 $20 \%$ 에서 $95 \%$ 로 증가시켰을 때 트리클로로에틸렌과 테트라클로로에틸렌의 평균 제어효율이 각각 약 $100 \%$ 에서 $23 \%$ 그리고 약 $100 \%$ 에서 $8 \%$ 로 대폭 감소하였다. 본 연구결과를 종합해볼 때, 작동조건을 최적화할 경우 폴리아닐린-이산화티타 늄 복합체가 일반 공기질 농도 수준의 염소계 화합물질 제어를 위해서 효율적으로 이용될 수 있는 것으로 나타났다.

주제어 : 전도체 고분자, 소성온도, 실내공기질 수준, 트리클로로에틸렌, 테트라클로로에틸렌

\begin{abstract}
In this study, polyaniline (PANI)-based $\mathrm{TiO}_{2}\left(\mathrm{PANI}-\mathrm{TiO}_{2}\right)$ composites calcined at different temperatures were prepared and their applications for control of trichloroethylene (TCE) and tetrachloroethylene (TTCE) at indoor air levels were investigated. For these target compounds, the photocatalytic control efficiencies of $\mathrm{PANI}_{-} \mathrm{TiO}_{2}$ composites did not exhibit any trend with varying calcination temperatures (CTs). Rather, the average control efficiencies of $\mathrm{PANI}_{-} \mathrm{TiO}_{2}$ composites over 3-h photocatalytic process increased from 61 to $72 \%$ and from 21 to $39 \%$ for TCE and TTCE, respectively, as the CT increased from 350 to $450{ }^{\circ} \mathrm{C}$. However, for both the target compounds, the average control efficiencies of $\mathrm{PANI}_{\mathrm{TiO}} \mathrm{T}_{2}$ composites decreased gradually as the CT increased further to 550 and $650{ }^{\circ} \mathrm{C}$. These results were ascribed to contents of anatase crystal phase and specific surface area of different particle sizes in the $\mathrm{PANI}-\mathrm{TiO}_{2}$ composites, which were demonstrated by the X-ray diffraction and scanning electron microscopy images, respectively. At the lowest input concentration (IC, $0.1 \mathrm{ppm}$ ), average control efficiencies of TCE and TTCE were 72 and $39 \%$, respectively, whereas at the highest IC (1.0 ppm) they were 52 and $18 \%$, respectively. As stream flow rate increased from 0.1 to $1.0 \mathrm{~L} \mathrm{~min}^{-1}$, the average control efficiencies of TCE and TTCE decreased from ca. 100 to $47 \%$ and ca. 100 to $18 \%$, respectively. In addition, the average control efficiencies of TCE and TTCE decreased from ca. 100 to $23 \%$ and ca. 100 to $8 \%$, respectively as the relative humidity increased from 20 to $95 \%$. Overall, these findings indicated that as-prepared $\mathrm{PANI}_{-} \mathrm{TiO}_{2}$ composites could be used efficiently for control of chlorinated compounds at indoor air levels, if operational conditions were optimized.
\end{abstract}

Keywords : Conducting polymer, Calcination temperature, Indoor air level, Trichloroethylene, Tetrachloroethylene

\section{Introduction}

Photocatalytic oxidation process using titania $\left(\mathrm{TiO}_{2}\right)$, which is

\footnotetext{
* To whom correspondence should be addressed. E-mail: wkjo@knu.ac.kr
}

doi:10.7464/ksct.2013.19.2.105 an advanced oxidation technologies, has been extensively applied to cleaning of a range of contaminants in water and air media, because $\mathrm{TiO}_{2}$ photocatalysts could degrade those environmental pollutants with high oxidation capacities[1-3]. $\mathrm{TiO}_{2}$ is the most popular semiconductor for photocatalytic applications primarily due to photocatalytic degradation potential, high chemical stabi- 
lity, and low price[3]. However, this photocatalyst has a major drawback of low oxidation capacity to a variety of environmental pollutants[3]. In recent, several supporting substrates have been proposed to improve photocatalytic performance of $\mathrm{TiO}_{2}$. The popular supporting substrates included opaque powder- and fiber-type carbon materials[4,5], transparent silica gel[6], glass beads[7] and glass tubes[8], and opaque polymeric materials[911]. Among these substrates, conducting polymer materials have received a special attention as supporting materials for the enhancement of photocatalytic performance of $\mathrm{TiO}_{2}$ powder[9-11].

In particular, polyaniline (PANI)- $\mathrm{TiO}_{2}$ composite has been known as a promising conducting polymer-inorganic composite mainly owing to the synergistic effect of unique electrical and photo-absorbance properties[11]. Moreover, PANI has excellent conductivity and good environmental stability[12]. Liao et al. [13] reported that coupling of PANI to $\mathrm{TiO}_{2}$ powder could induce effective charge separation of photoinduced carriers, which would result from heterojunction generated between the polymer and semiconductor materials. This phenomenon appeared to lower electron-hole recombination, thereby enhancing photocatalytic activity of the photocatalyst composites. Accordingly, certain studies[11-13] have reported that the photocatalytic activity of PANI-TiO 2 composites was higher than that of pure $\mathrm{TiO}_{2}$ powders for control of aqueous-phase pollutants, such as phenol, methylene orange, rhodamine $\mathrm{B}$, and 4-chlorophenol. It is noteworthy that light absorbance mechanisms and heterogeneous photocatalytic oxidation kinetics differ between water-solid and air-solid interfaces[14]. This assertion indicates that the photocatalytic activity obtained from water-solid photocatalytic process might not reflect that for gas-solid photocatalytic process, thereby leading to the need to investigate the application of PANI$\mathrm{TiO}_{2}$ composites to air cleaning applications. Nevertheless, little studies were performed on the application of $\mathrm{PANI}^{-\mathrm{TiO}_{2}}$ composites for control of gas-phase pollutants.

Accordingly, the current study was performed to prepare PANI$\mathrm{TiO}_{2}$ composites using a hydrothermal method and to examine their surface and morphological characteristics and their photocatalytic activities for the control of two toxic chlorinated volatile pollutants at indoor air levels. Moreover, $\mathrm{PANI}-\mathrm{TiO}_{2}$ composites were prepared under different calcination temperature conditions to evaluate their effects on degradation efficiencies of the target compounds. The photocatalytic activity test was conducted using a continuous-flow reactor under visible- as well as UV-light irradiation. For comparison, the photocatalytic activity of commercially-available Degussa P25 $\mathrm{TiO}_{2}$ with the same weight as that of a PANI-TiO ${ }_{2}$ composite was also assessed. Two target compounds, trichloroethylene (TCE) and tetrachloroethylene (TTCE), were chosen on the basis of their prevalence and toxic effects. These pollutants are one of the volatile pollu- tant groups that are typically detected at higher concentrations in indoor air compared to outdoor air[15]. In addition, these compounds have been classified as a toxic chemical group suspected of being carcinogenic and mutagenic[16].

\section{Methods}

\subsection{Photocatalytic reactor and experimental procedure}

A plug-flow annular-type reactor (Pyrex tube with $4.5 \mathrm{~cm}$ inside diameter and $26.5 \mathrm{~cm}$ length) whose inner was coated with a thin film of PANI-TiO ${ }_{2}$ composites or a thin film of Degussa $\mathrm{P} 25 \mathrm{TiO}_{2}$ photocatalyst as a reference photocatalyst. The photocatalytic efficiencies of the photocatalysts were investigated for the control of TCE and TTCE at indoor air levels. For this purpose, photocatalyst powders were ground and added to $0.1 \mathrm{M}$ ethylenediaminotetraacetic acid solution, which was then diluted by adding dropwise deionized water and Triton X-100. Subsequently, the resulting sol was pasted onto the inner wall surface of the Pyrex tube. This pasted reactor was dried in an oven at $100{ }^{\circ} \mathrm{C}$ for $0.5 \mathrm{~h}$ and then calcined in a furnace at $350{ }^{\circ} \mathrm{C}$ for 0.5 h. A 8-W fluorescent UV lamp (F8T5BL, Youngwha Lamp Co.) was installed inside the Pyrex tube and acted as the inside surface boundary of the annular-type photocatalytic reactor. Clean dried air which was re-purified with a charcoal filter was supplied by a compressed air cylinder and was humidified by passing it through then water-contained glass apparatuses, which were immersed in a temperature-controlled water bath. Standard VOCs were prepared by injecting the target compounds into a mixing container via an auto-programmed syringe pump (Model Legato 100, KdScientific Inc.). The standard VOC stream was directed to a buffering chamber to minimize the inlet concentration fluctuation and then fed into the reactor. The stream flow rate (FR) was determined using mass flow controllers (Defender 510 , Bios International Co.) and relative humidity ( $\mathrm{RH})$ was measured via a humidity meter (TR-72S, T\&D Co.).

The PANI-supported $\mathrm{TiO}_{2}$ composites with different calcination temperatures were synthesized using a hydrothermal method. $3.6 \mathrm{~mL}$ of Titanium (IV) chloride (TiCl4 98\%, Aldrich Inc.) was mixed with $43.8 \mathrm{~mL}$ of deionzed water in a flask partially immersed in ice-water bath and then $4.4 \mathrm{~g}$ of ammonium sulfate $\left(\left(\mathrm{NH}_{4}\right)_{2} \mathrm{SO}_{4} 99.5 \%\right.$, Aldrich Inc.) and $36 \mathrm{~g}$ of urea (CO $\left(\mathrm{NH}_{2}\right)_{2} \quad 100 \%$, Aldrich Inc.) were added dropwise to this mixture. Next, this solution was stirred for $4 \mathrm{~h}$ and subsequently $44.8 \mathrm{~mL}$ of ethanol $\left(\mathrm{C}_{2} \mathrm{H}_{5} \mathrm{OH} 99.9 \%\right.$, Aldrich Inc. $)$ was added to this solution. $70 \mathrm{~mL}$ of this solution was transferred into a $100 \mathrm{~mL}$ Teflon-lined autoclave and then heated at $95{ }^{\circ} \mathrm{C}$ for 24 h. When thermal treatment was completed, the autoclave was cooled down for $20 \mathrm{~h}$ to room temperature. The resultant solution was filtered to obtain precipitates and washed with ethanol 
and deionized water. The filtered precipitate was calcined at 350 , 450,550 , or $650{ }^{\circ} \mathrm{C}$ for $2 \mathrm{~h}$ to get $\mathrm{TiO}_{2}$ powder. Subsequently, these $\mathrm{TiO}_{2}$ powders were mixed with $\mathrm{PANI}+$ tetrahydrofuran $\left(\mathrm{C}_{4} \mathrm{H}_{8} \mathrm{O} 99.9 \%\right.$, Aldrich Inc.) solution. Next, this mixture was sonicated for $30 \mathrm{~min}$, stirred for $24 \mathrm{~h}$, and then filtered to obtain precipitate. The resulting precipitates were washed with ethanol and deionized water, and then dried at $80{ }^{\circ} \mathrm{C}$ for $12 \mathrm{~h}$ to obtain final PANI-TiO ${ }_{2}$ composites.

The photocatalytic tests of the as-prepared $\mathrm{PANI}-\mathrm{TiO}_{2}$ composites were conducted under different experimental conditions. Four calcination temperatures (CTs) with a range of 350-650 ${ }^{\circ} \mathrm{C}\left(350,450,550\right.$, and $\left.650{ }^{\circ} \mathrm{C}\right)$ and four FRs with a range of 1.0-4.0 L min $\min ^{-1}\left(0.1,0.3,0.7\right.$, and $\left.1.0 \mathrm{~L} \mathrm{~min}^{-1}\right)$ were tested for this study. In addition, inlet concentration (IC) of target compounds ranged from $0.1-1.0 \mathrm{ppm}(0.1,0.3,0.7$, and $1.0 \mathrm{ppm})$, and RHs ranged from 20-95\% (20, 45, 70, and 95\%). For each variable test, other variables were fixed to their representative value: $\mathrm{CT}, 450{ }^{\circ} \mathrm{C}$; FR, $0.3 \mathrm{~L} \mathrm{~min}^{-1}$; IC, $0.1 \mathrm{ppm}$; and $\mathrm{RH}, 45 \%$. For comparison, the photocatalytic efficiency of a reference Degussa P-25 $\mathrm{TiO}_{2}$ photocatalyst with same $\mathrm{TiO}_{2}$ weight $(0.36 \mathrm{mg}$ $\mathrm{cm}^{-2}$ ) as that of the PANI-TiO ${ }_{2}$ composite was also investigated under the operational conditions of the representative values.

The surface characteristics of the PANI- $\mathrm{TiO}_{2}$ composites calcined at different temperatures were investigated using X-ray diffraction (XRD) image, scanning electron microscopy (SEM), ultraviolet-visible (UV-VIS) spectroscopy, and Fourier transforms infrared (FTIR) spectroscopy. The crystal structure of the $\mathrm{PANI}^{-\mathrm{TiO}_{2}}$ composites were determined on a Rigaku D/max2500 diffractometer with $\mathrm{Cu} \mathrm{K} \alpha$ radiation, which was operated at $40 \mathrm{kV}$ and $100 \mathrm{~mA}$ in the range of $20-80^{\circ}(2 \theta)$ at a scanning rate of $10^{\circ} \mathrm{min}^{-1}$. The particle morphology of the samples was examined by FE-SEM S-4300 and EDX-350 FE-SEM (Hitachi Co.) at an acceleration voltage of $15 \mathrm{kV}$. Photo absorption properties were observed using a diffuse reflectance UV-VIS-near

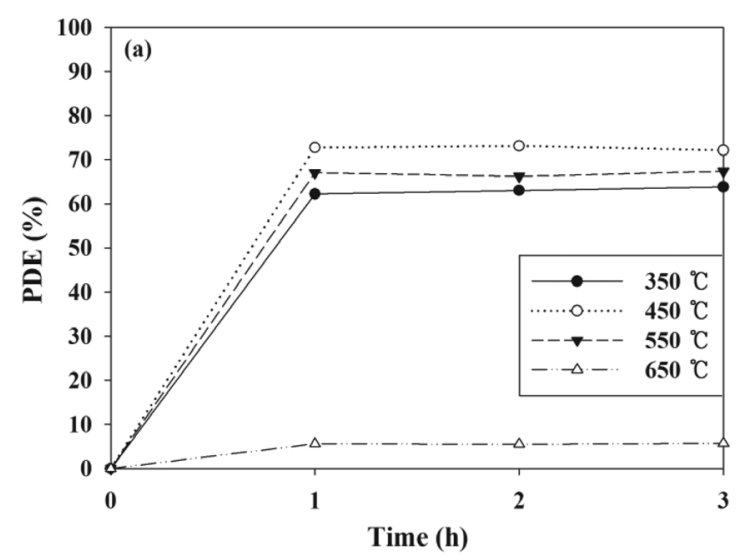

IR Varian CARY 5G spectrophotometer equipped with an integrating sphere. The structural information of the samples was obtained from a FTIR spectrophotometer (Spectrum GX, PerkinElmer Inc.) under conditions of a resolution of $4 \mathrm{~cm}^{-1}$. Specific surface areas were determined using $\mathrm{N}_{2}$ sorption analysis with a Micromeritics ASAP 2020 instrument.

\subsection{Measurement of air-stream species}

Measurements of gas compounds were performed at the inlet and outlet sides of the plug-flow annular-type photocatalytic reactor. Gas samples were collected using a Tedlar bag, after which air from this bag was drawn through a Tenax adsorbent trap. VOCs adsorbed on the trap were analyzed using a pretreatment automatic thermal desorber (ATD 400, Perkin Elmer Co.) and a gas chromatograph (GC, 7890, Agilent Inc.) equipped with a flame ionization detector and a capillary column (DB-5, Agilent Co.). The VOCs were qualitatively evaluated according to their retention times on the GC chromatogram and quantitatively evaluated using calibration curves. The data quality control program for the VOC measurements consisted of laboratory blank traps and spiked traps. On each analysis day, one laboratory blank sample was analyzed to confirm no contamination of the traps. And one external standard of the mixture of target compounds was analyzed to confirm the quantitative response of the GC. The detection limits of TCE and TTCE were determined to be $0.01 \mathrm{ppm}$ and $0.02 \mathrm{ppm}$, respectively.

\section{Results and discussion}

Photocatalytic control efficiencies of $\mathrm{PANI}-\mathrm{TiO}_{2}$ composites were investigated under a variety of experimental conditions by varying the $\mathrm{CT}, \mathrm{FR}, \mathrm{IC}$, and $\mathrm{RH}$. Figure 1 presents the photocatalytic control efficiencies of $\mathrm{PANI}-\mathrm{TiO}_{2}$ composites synthesized under different CT conditions over a 3-h photocatalytic process.

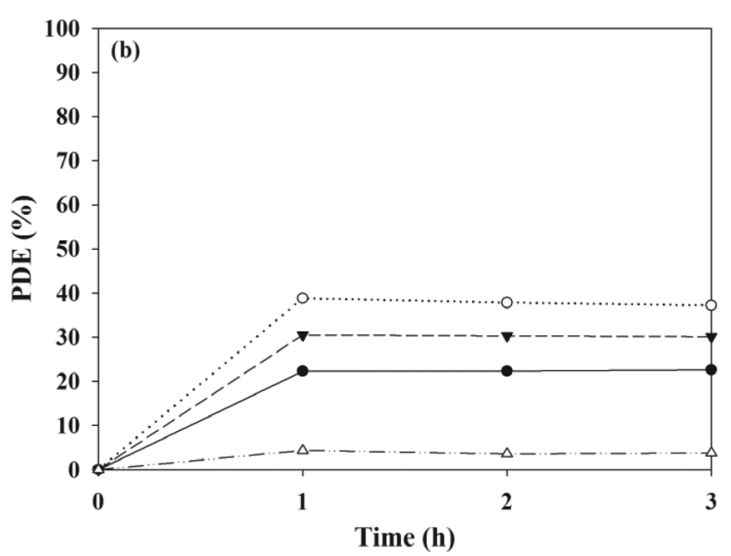

Figure 1. Photocatalytic degradation efficiency (PDE) of TCE and TTCE determined using (a) $\mathrm{PANI}_{-\mathrm{TiO}} \mathrm{C}_{2}$ composites calcined at different calcination temperatures and (b) Degussa $\mathrm{P} 25 \mathrm{TiO}_{2}$. 


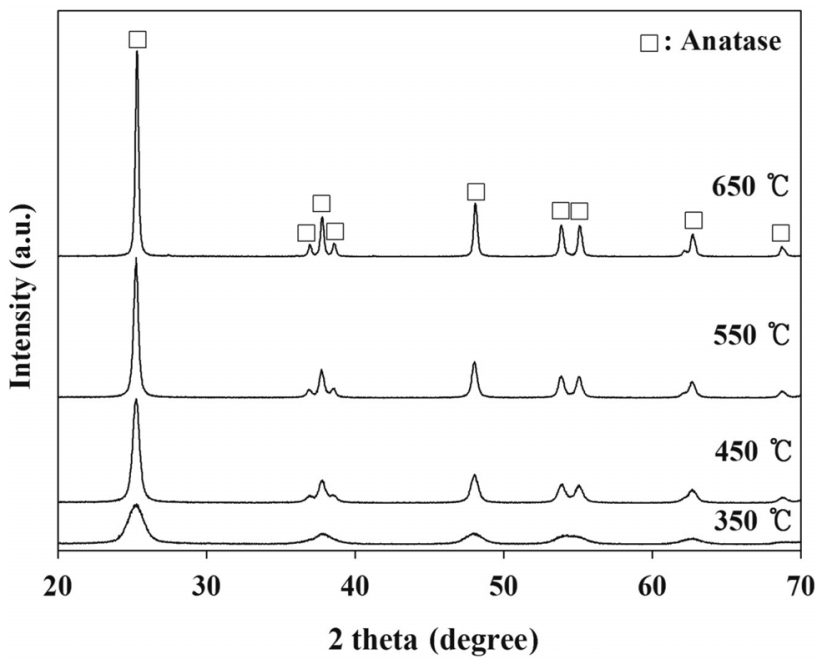

Figure 2. X-ray diffraction image of $\mathrm{PANI}-\mathrm{TiO}_{2}$ composites calcined at different calcination temperatures.

For both indoor air-level TCE and TTCE, the photocatalytic efficiency reached rapidly to maximum value in one hour, which was attributed to short photocatalytic oxidation times with less than $1 \mathrm{~min}(5.48-54.80 \mathrm{sec})$ in the plug-flow reactor systems used in this study. The average control efficiencies of $\mathrm{PANI}_{-} \mathrm{TiO}_{2}$ composites over 3-h photocatalytic process increased from 61 to $72 \%$ and from 21 to $39 \%$ for TCE and TTCE, respectively, as the CT increased from 350 to $450{ }^{\circ} \mathrm{C}$. However, for both the target VOCs, the average control efficiencies of $\mathrm{PANI}_{-\mathrm{TiO}}$ composites decreased gradually as the $\mathrm{CT}$ increased further to 550 and $650{ }^{\circ} \mathrm{C}$. These results were ascribed to different mor- phological and electronic properties of $\mathrm{PANI}-\mathrm{TiO}_{2}$ composites synthesized under different calcination temperature conditions, which could yield different photocatalytic behaviors. According to $\mathrm{XRD}$ results (Figure 2), all $\mathrm{PANI}-\mathrm{TiO}_{2}$ composites showed rutile crystal phase but not anatase crystal phase, which were similar to results reported in previous studies[11,13]. However, more distinct peaks were observed for the $\mathrm{PANI}-\mathrm{TiO}_{2}$ composite calcined at $450{ }^{\circ} \mathrm{C}$ compared to the PANI-TiO ${ }_{2}$ composite calcined at $450{ }^{\circ} \mathrm{C}$, suggesting superior photocatalytic performance of the former photocatalyst for the control of TCE and TTCE. Meanwhile, as shown in Figure 3, the SEM images reveals that the particle size of the PANI-TiO 2 composites increased as the CT increased, thereby resulting in low volume-to-surface area for the composites calcined at higher temperature. This assertion was supported by the BET areas of $\mathrm{PANI}-\mathrm{TiO}_{2}$ composites calcined at four different calcination temperatures (Table 1). Accordingly, the higher control efficiencies of the $\mathrm{PANI}-\mathrm{TiO}_{2}$ composite calcined at $450{ }^{\circ} \mathrm{C}$ than the $\mathrm{PANI}-\mathrm{TiO}_{2}$ composites calcined at 550 ${ }^{\circ} \mathrm{C}$ and $650{ }^{\circ} \mathrm{C}$ were attributed to high volume-to-surface area.

Table 1. BET surface area of $\mathrm{PANI}-\mathrm{TiO}_{2}$ composites calcined at different calcination temperatures

\begin{tabular}{c|c}
\hline Calcination temperature $\left({ }^{\circ} \mathrm{C}\right)$ & Area $\left(\mathrm{m}^{2} \mathrm{~g}^{-1}\right)$ \\
\hline \hline 350 & 135 \\
450 & 122 \\
550 & 106 \\
650 & 91 \\
\hline
\end{tabular}
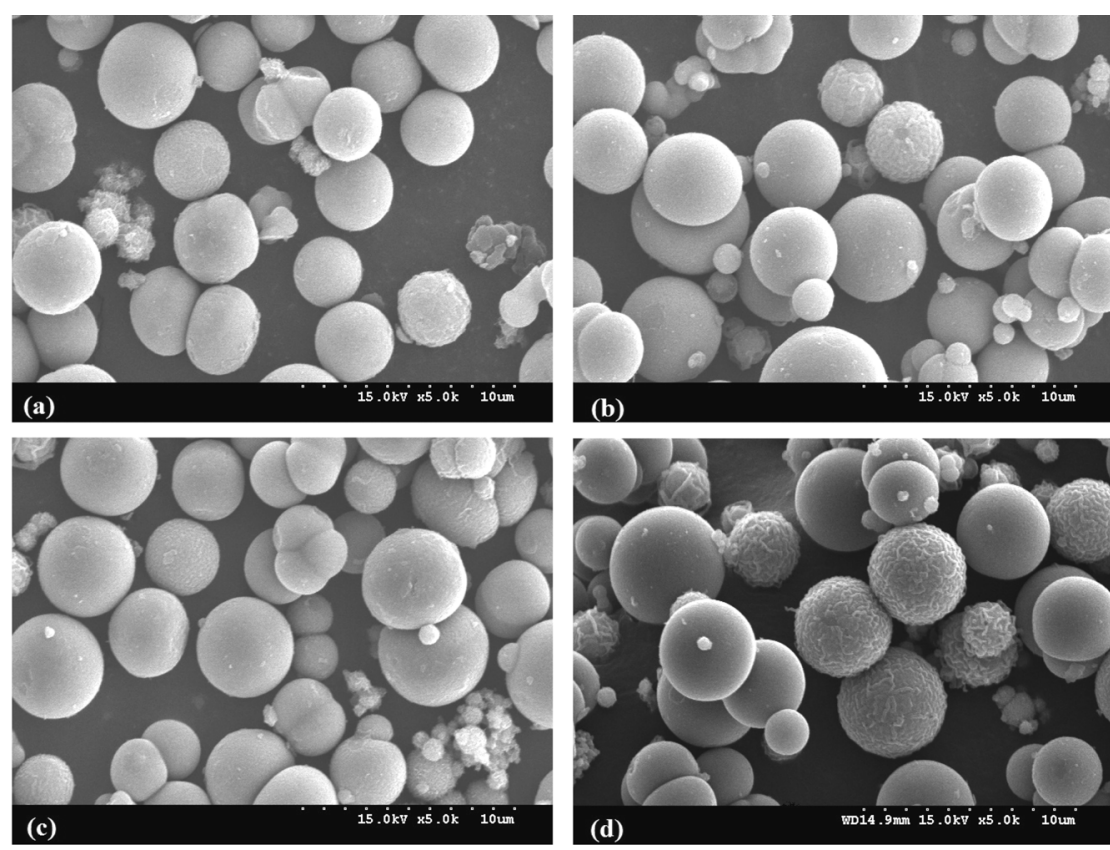

Figure 3. Scanning electron microscopy of $\mathrm{PANI}-\mathrm{TiO}_{2}$ composites calcined at different calcination temperatures ((a) 350, (b) 450, (c) 550, and (d) $650{ }^{\circ} \mathrm{C}$ ). 


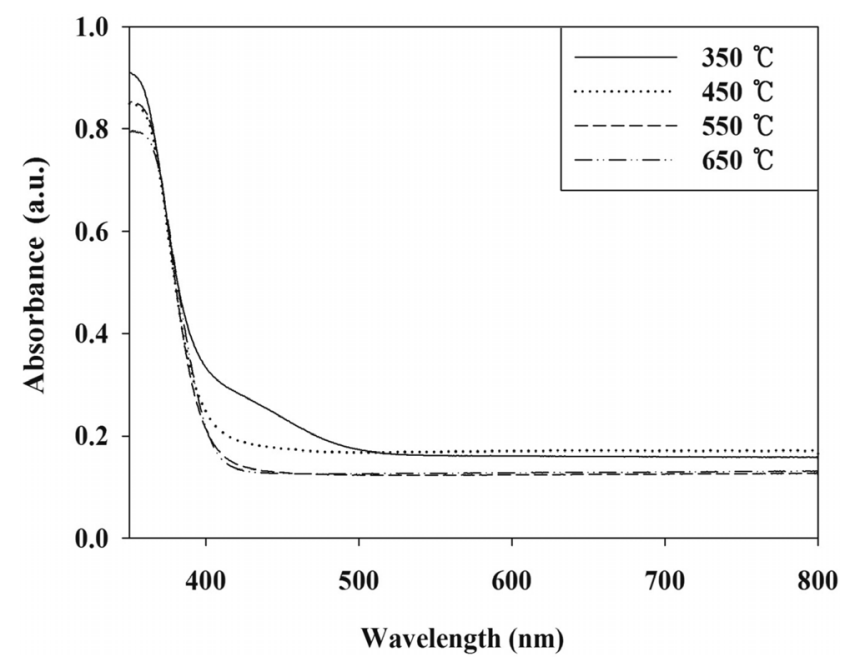

Figure 4. UV-visible absorption spectra of $\mathrm{PANI}_{-\mathrm{TiO}}$ composites calcined at different calcination temperatures.

Moreover, the higher control efficiencies of the PANI- $\mathrm{TiO}_{2}$ composite calcined at $450{ }^{\circ} \mathrm{C}$ is supported by UV-VIS absorption intensity at UV range. Figure 4 exhibits that the $\mathrm{PANI}-\mathrm{TiO}_{2}$ composite calcined at $450{ }^{\circ} \mathrm{C}$ could absorb stronger UV compared to the PANI-TiO 2 composites calcined at 550 and $650{ }^{\circ} \mathrm{C}$, which would enhance photocatalytic performance for the removal of TCE and TTCE. It was notable that, even though the UV absorbance intensity of PANI-TiO ${ }_{2}$ composite calcined at $350{ }^{\circ} \mathrm{C}$ were stronger than that obtained from the $\mathrm{PANI}_{-} \mathrm{TiO}_{2}$ composite calcined at $450{ }^{\circ} \mathrm{C}$, the photocatalytic control efficiencies of PANI-TiO ${ }_{2}$ composite calcined at $350{ }^{\circ} \mathrm{C}$ were lower than those obtained from the $\mathrm{PANI}-\mathrm{TiO}_{2}$ composite calcined at 450 ${ }^{\circ} \mathrm{C}$. These results suggested that the anatase crystal formation effect would outweigh UV absorbance effect on control efficiencies of TCE and TTCE.

The FTIR spectra of the PANI-TiO 2 composites synthesized at different CTs are presented in Figure 5. The FTIR spectra of

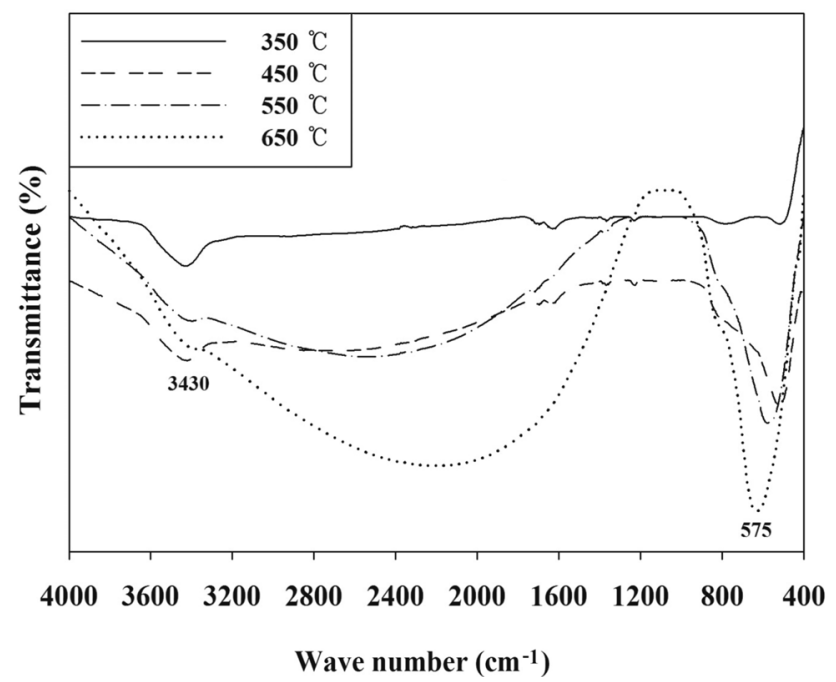

Figure 5. Fourier transform infrared spectra of $\mathrm{PANI}-\mathrm{TiO}_{2}$ composites calcined at different calcination temperatures.

the PANI-TiO 2 composites were similar to each other, although the transmittance intensity was somewhat different. Major absorption peaks appeared at bands of 3,430 and $575 \mathrm{~cm}^{-1}$. The band of $3,430 \mathrm{~cm}^{-1}$ was assigned to N-H stretching[12]. The low frequency bands around $575 \mathrm{~cm}^{-1}$ were likely due to the Ti-OTi vibration of anatase[17]. These findings confirmed the presence of anatase crystal phase in the $\mathrm{PANI}-\mathrm{TiO}_{2}$ composites prepared in the present study, which supported the XRD results above. Meanwhile, no bands around $708 \mathrm{~cm}^{-1}$ which were associated with the Ti-O-Ti vibration of rutile[18,19], demonstrating again the absence of rutile crystal phase in the $\mathrm{PANI}_{-\mathrm{TiO}}$ composites prepared in this study. In addition, the band around $1,200 \mathrm{~cm}^{-1}$ was ascribed to the formation of $\mathrm{C}-\mathrm{O}$ functional group[20].

Figure 6 represents the control efficiencies the $\mathrm{PANI}_{-\mathrm{TiO}}$ composite calcined at $450{ }^{\circ} \mathrm{C}$ over a 3-h photocatalytic process ac-
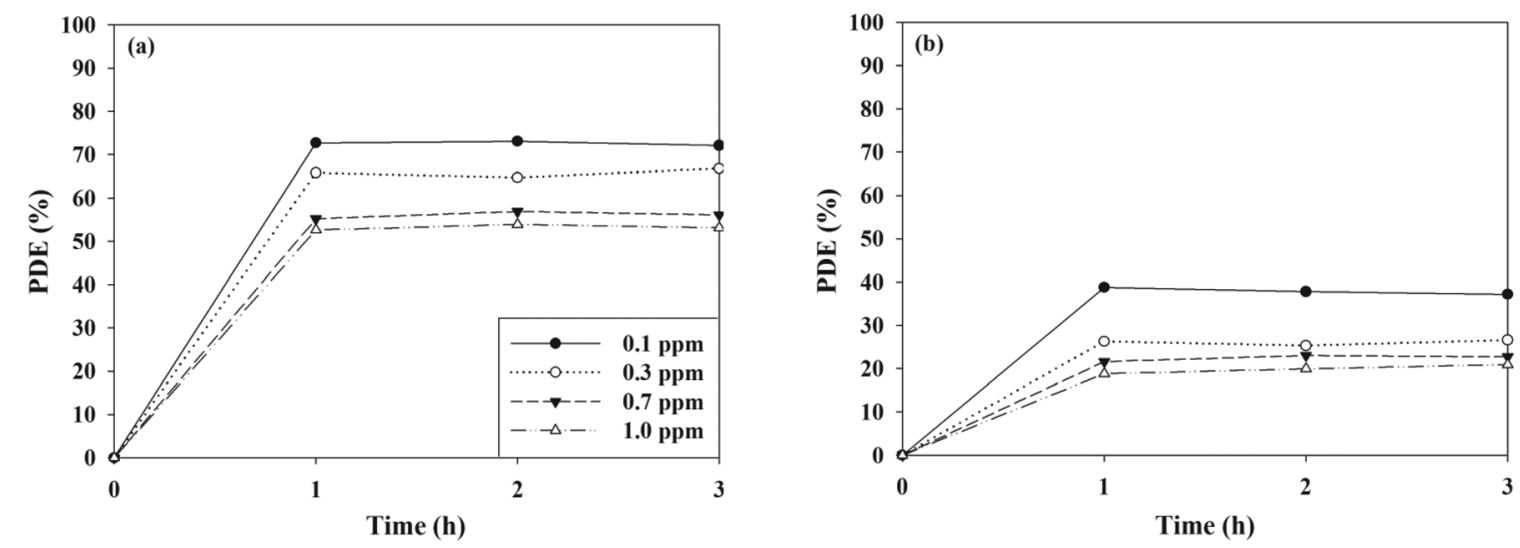

Figure 6. Photocatalytic degradation efficiency (PDE) of (a) TCE and (b) TTCE determined using a PANI-TiO 2 composite calcined at $450{ }^{\circ} \mathrm{C}$ according to inlet concentration $(0.1,0.3,0.7$, and $1.0 \mathrm{ppm})$. 
cording to ICs that cover indoor air levels. For two target compounds, the photocatalytic control efficiencies exhibited a decreasing trend as IC increased. At the lowest IC $(0.1 \mathrm{ppm})$, average control efficiencies of TCE and TTCE were 72 and 39\%, respectively, whereas at the highest IC $(1.0 \mathrm{ppm})$ they were 52 and $18 \%$, respectively. The adsorption of pollutants on the surface of the catalyst was a major cause for the photocatalytic oxidation of chemical compounds[21,22]. This suggested that the increasing trend in control efficiency with increasing of IC would result from competitive adsorption between pollutant molecules on the photocatalyst surface. Moreover, at high ICs a limited amount of the adsorption sites on the surface of the PANI-TiO ${ }_{2}$ composites could be available for the adsorption of TCE and TTCE molecules before photocatalytic oxidation[22]. Consistently, Devahasdin et al.[23] reported that photocatalytic control efficiencies for nitrogen oxide (NO), which were determined via an UV-irradiated $\mathrm{TiO}_{2}$ system, decreased from 70 to $15 \%$ as IC increased from 5 to $60 \mathrm{ppm}$. Yu and Brouwers[24] also found that found that NO decomposition efficiencies, which were determined via a photocatalytic reactor with carbon-doped $\mathrm{TiO}_{2}$ under visible-light irradiation, decreased from 61 to 16 as IC increased from 0.1 to $1.0 \mathrm{ppm}$.

The control efficiencies of $\mathrm{PANI}-\mathrm{TiO}_{2}$ composite calcined at $450{ }^{\circ} \mathrm{C}$ over a 3-h photocatalytic process according to FR are shown in Figure 7. For both the two target VOCs, the control efficiency decreased as the FR increased. Specifically, as the FR increased from 0.1 to $1.0 \mathrm{~L} \mathrm{~min}^{-1}$, the average control efficiencies of TCE and TTCE decreased from ca. 100 to $47 \%$ and ca. 100 to $18 \%$, respectively. Similarly, Yu and Brouwers[24] reported that NO photocatalytic control efficiency decreased from to 62 to $13 \%$ as FR increased from 1 to $5 \mathrm{~L} \mathrm{~min}^{-1}$. The bulk mass transport of target compounds from the gas-phase to the surface of the catalyst particle is an important heterogeneous catalytic reaction process[25]. Accordingly, as FR increased, the bulk mass transport of TCE and TTCE molecules would increase primarily owing to convection and diffusion. In addition, the retention times for the FRs of $0.1,0.3,0.5$, and $1.0 \mathrm{~L} \mathrm{~min}^{-1}$, which were determined by dividing the reactor volume by the FRs, were 134, 45, 27, and 13 s, respectively. Accordingly, the lower TCE and TTCE control efficiencies for high FRs were assigned to an insufficient retention time in the photocatalytic reactor.

The effects of a wide range of $\mathrm{RH}$ values that cover both dried and humidified environmental conditions on the control efficiencies of TCE and TTCE were evaluated using the PANI-TiO composite calcined at $450{ }^{\circ} \mathrm{C}$ over a 3 -h photocatalytic process. As presented in Figure 8, the control efficiencies of two target compounds decreased with increasing RH. Specifically, as the $\mathrm{RH}$ increased from 20 to $95 \%$, the average control efficiencies of TCE and TTCE decreased from ca. 100 to $23 \%$ and ca. 100 to $8 \%$, respectively. This pattern was consistent with that determined using a UV-irradiated $\mathrm{TiO}_{2}$ system, which was reported in Zhao et al.[26] study. Under low RH conditions, there is a shortage or absence of water molecules and as a result, photocatalytic reactions could be retarded owing to an insufficient hydroxyl groups, which could oxidize TCE and TTCE molecules on the surface of the PANI-TiO 2 composites. On the other hand, excessive water vapor could compete with TCE and TTCE molecules for the adsorption sites on the surface of the PANI-TiO composites. Accordingly, low photocatalytic control efficiency under high RH conditions was ascribed to the competition between TCE or TTCE and water molecules for adsorption on the surface of the PANI-TiO ${ }_{2}$ composites. However, Jeong et al.[27] reported that photocatalytic efficiencies of a UV-irradiated $\mathrm{TiO}_{2}$ system for gaseous toluene control increased as $\mathrm{RH}$ increased from less than 1 to $50 \%$ and then remained constant while $\mathrm{RH}$ increased from 50 to $95 \%$. In their study, an increased population of hydroxyl radicals, which would be formed due to
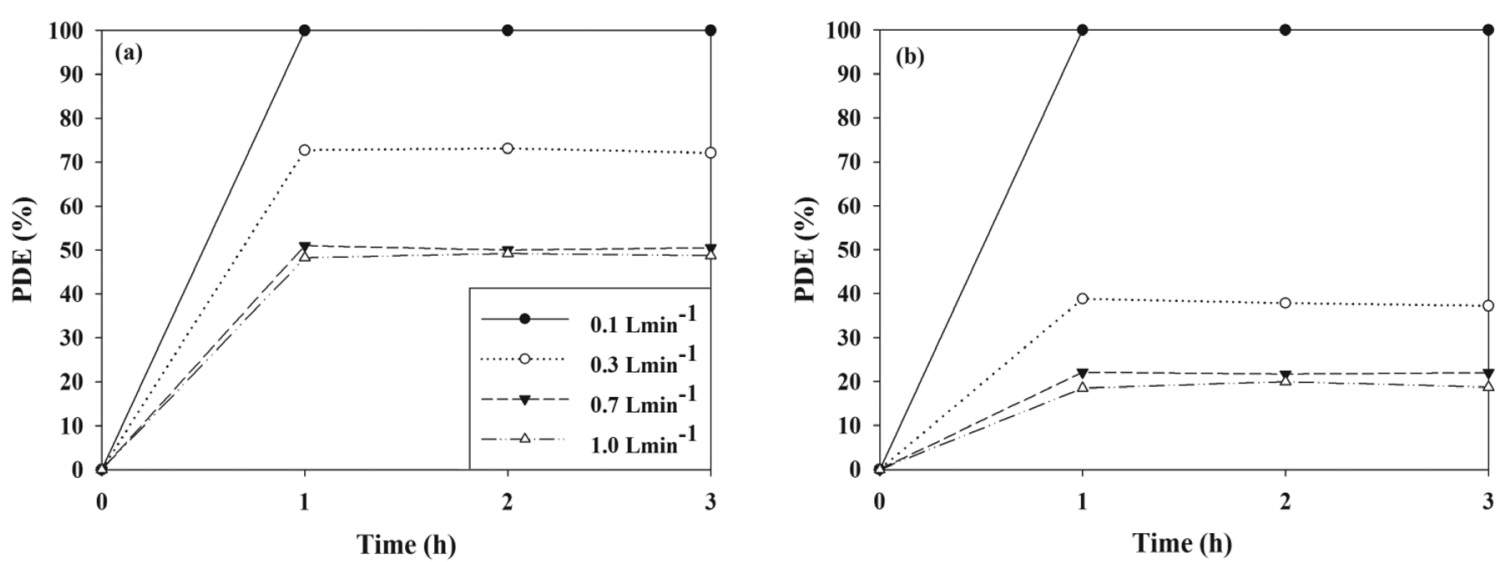

Figure 7. Photocatalytic degradation efficiency (PDE) of (a) TCE and (b) TTCE determined using a PANI-TiO ${ }_{2}$ composite calcined at $450{ }^{\circ} \mathrm{C}$ according to flow rate. 

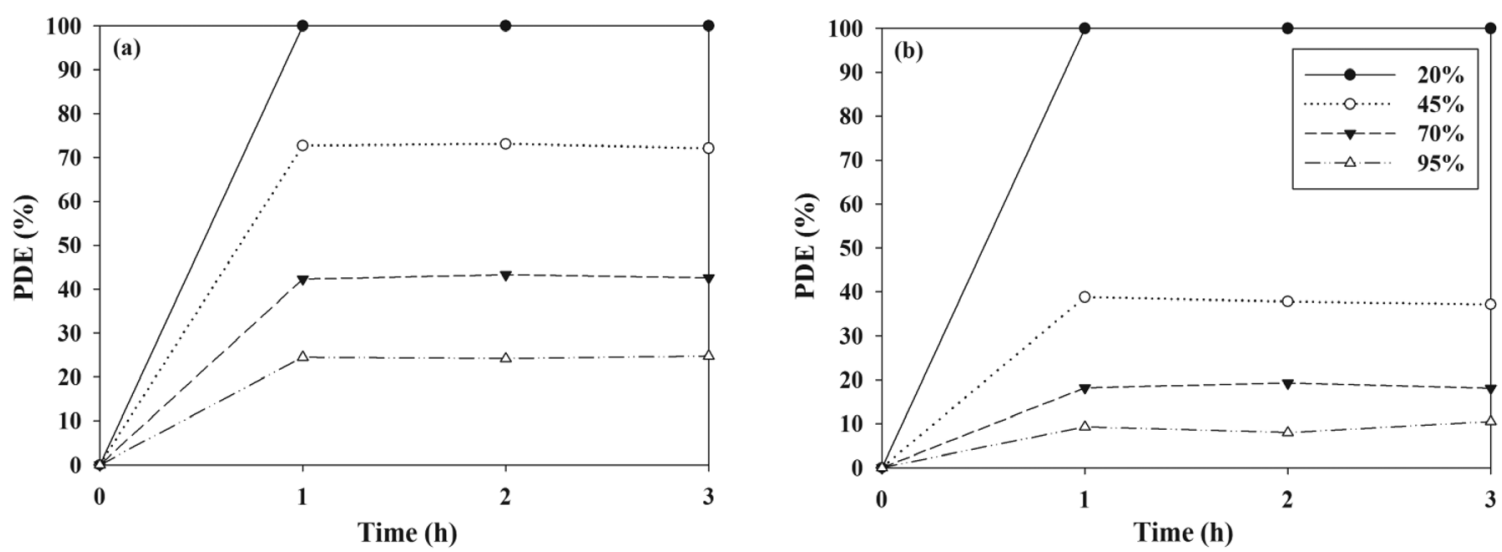

Figure 8. Removal efficiency (RE) of (a) TCE and (b) TTCE determined using a PANI-TiO 2 composite calcined at $450{ }^{\circ} \mathrm{C}$ according to relative humidity.

elevated water vapor, was provided as an explanation for the increase in toluene photocatalytic control efficiencies. Consequently, these contrasting $\mathrm{RH}$ effects on photocatalytic control efficiency were attributed to the amount of water vapor as well as the type and input concentration of target VOCs applied to this and previous studies.

\section{Conclusions}

The current study examined the application of $\mathrm{PANI}_{-} \mathrm{TiO}_{2}$ composites calcined at different temperatures for the photocatalytic control of indoor air level TCE and TTCE. Within the $\mathrm{CT}$ range specified in this study, the control efficiencies of the PANI-TiO 2 composites fluctuated as the $\mathrm{TiO}_{2}$ ratio varied, without exhibiting any increasing or decreasing trend. These results were ascribed to contents of anatase crystal phase and specific surface area of different particle sizes in the PANI-TiO composites, which were demonstrated by the SEM and XRD images, respectively. In addition, the findings presented herein suggested that indoor air quality concentration levels, hourly air treatment volume, and indoor air humidity were all important parameters that should be considered to enable effective operation of the PANI-TiO ${ }_{2}$ composites for the photocatalytic control of indoor TCE and TTCE. Taken together, the results represented herein suggested that the PANI-TiO ${ }_{2}$ composite could be used efficiently for control of indoor chlorinated hydrocarbons, when photocatalytic operational conditions were optimized.

\section{Acknowledgement}

This work was supported by the National Research Foundation of Korea (NRF) grant funded by the Korean government (MEST) (2011-0027916) and Kyungpook National University Research Fund, 2012.

\section{References}

1. Yun, T. K., Bae, J. Y., Park, S. S., and Won Y. S., "Synthesis and Electrochemical Properties of Nitrogen Doped Mesoporous $\mathrm{TiO}_{2}$ Nanoparticles as Anode Materials for Lithium-ion Batteries," Clean Tech., 18(2), 177-182 (2012).

2. Ahmed, S., Rasul, M. G., Brown, R., and Hashib, M. A., "Influence of Parameters on the Heterogeneous Photocatalytic Degradation of Pesticides and Phenolic Contaminants in Wastewater: A Short Review," J. Environ. Manage., 92, 311-330 (2011).

3. Lee, G. Y., Park, Y. J., Park, N. K., Lee, T. J., and Kang, M. S., "Hydrogen Production from Photocatalytic Splitting of Methanol/water Solution over Ti Impregnated $\mathrm{WO}_{3}$," Clean Tech., 18(4), 355-359 (2012).

4. Matos, J., García-López, E., Palmisano, L., García, A., and Marcì, G., "Influence of Activated Carbon in $\mathrm{TiO}_{2}$ and $\mathrm{ZnO}$ Mediated Photo-assisted Degradation of 2-Propanol in Gassolid Regime," Appl. Catal. B: Environ., 99, 170-180 (2010).

5. Shi, J.-W., Cui, H. J., Chen, J.-W., Fu, M. L., Xu, B., Luo, H.-Y., and Ye, Z.-L., "TiO $2 /$ Activated Carbon Fibers Photocatalyst: Effects of Coating Procedures on the Microstructure, Adhesion Property, and Photocatalytic Ability," J. Colloid Interf. Sci., 388, 201-208 (2012).

6. Wang, Y. M., Liu, S. W., Xiu, Z., Jiao, X. B., Cui, X. P., and Pan, J., "Preparation and Photocatalytic Properties of Silica Gel-supported $\mathrm{TiO}_{2}$," Mater. Lett., 60, 975-978 (2006).

7. Verbruggen, S. W., Ribbens, S., Tytgat, T., Hauchecorne, B., Smits, M., Meynen, V., Cool, P., Martens, J. A., and Lenaerts, S., "The Benefit of Glass Bead Supports for Efficient Gas Phase Photocatalysis: Case Study of a Commercial and a Synthesised Photocatalyst," Chem. Eng. J., 174, 318-325 (2011).

8. Jo, W. K., and Kim, J. T., "Application of Visible-light Photocatalysis with Nitrogen-doped or Unmodified Titanium Dioxide for Control of Indoor-level Volatile Organic Compounds," J. Hazard. Mater., 164, 360-366 (2009). 
9. Kim, S., and Lim, S. K., "Preparation of $\mathrm{TiO}_{2}$-embedded Carbon Nanofibers and Their Photocatalytic Activity in the Oxidation of Gaseous Acetaldehyde," Appl. Catal. B: Environ., 84, 16-20 (2008).

10. Alves, A. K., Berutti, F. A., Clemens, F. J., Graule, T., and Bergmann, C. P., "Photocatalytic Activity of Titania Fibers Obtained by Electrospinning," Mater. Res. Bull., 44, 312-317 (2009).

11. Li, Q., Zhang, C., and Li, J., "Photocatalysis and Waveabsorbing Properties of Polyaniline $/ \mathrm{TiO}_{2}$ Microbelts Composite By in Situ Polymerization Method," Appl. Surf. Sci., 257, 944-948 (2010).

12. Li, X., Wang, D., Luo, Q., An, J., Wang, Y., and Cheng, G., "Surface Modification of Titanium Dioxide Nanoparticles by Polyaniline via an in Situ Method," J. Chem. Technol. Biotechnol., 83, 1558-1564 (2008).

13. Liao, G., Chen, S., Quan, X., Zhang, Y., and Zhao, H., "Remarkable Improvement of Visible Light Photocatalysis with Pani Modified Core-shell Mesoporous $\mathrm{TiO}_{2}$ Microspheres," Appl. Catal. B: Environ., 102, 126-131 (2011).

14. Fujishima, A., Zhang, X., and Tryk, D. A., " $\mathrm{TiO}_{2}$ Photocatalysis and Related Surface Phenomena," Surf. Sci. Rep., 63, 515582 (2008).

15. Jia, C., Batterman, S., and Godwin, C., "VOCs in Industrial, Urban And Suburban Neighborhoods-Part 2: Factors Affecting Indoor and Outdoor Concentrations," Atmos. Environ., 42, 2101-2116 (2008).

16. IARC (International Agency for Research on Cancer), "Monographs on the Evaluation of the Carcinogenic Risks of Chemicals to Man," WHO, Geneva, (2004).

17. Madaeni, S. S., Ghaemi, N., Alizadeh, A., and Joshaghani, M., "Influence of Photo-induced Superhydrophilicity of Titanium Dioxide Nanoparticles on the Anti-fouling Performance of Ultrafiltration Membranes," Appl. Surf. Sci., 257, 6175-6180 (2011).

18. Nagarajan, S., and Rajendran, N., "Surface Characterisation and Electrochemical Behaviour of Porous Titanium Dioxide Coated 3161 Stainless Steel for Orthopaedic Applications," Appl. Surf. Sci., 255, $3927-3932$ (2009).

19. Keswani, R. K., Ghodke, H., Sarkar, D., Khilar, K. C., and Srinivasa, R. S., "Room Temperature Synthesis of Titanium
Dioxide Nanoparticles of Different Phases in Water in Oil Microemulsion," Colloid. Surf. A: Physicochem. Eng. Asp., 369, 75-81 (2010).

20. Maréchal, A., Meunier, B., and Rich, P. R., “Assignment of the CO-sensitive Carboxyl Group in Mitochondrial Forms of Cytochrome C Oxidase Using Yeast Mutants," Biochim. Biophys. Acta, 1817, 1921-1924 (2012).

20. Bouzaza, A., Vallet, C., and Laplanche, A., "Photocatalytic Degradation of Some Vocs in the Gas Phase Using an Annular Flow Reactor: Determination of The Contribution of Mass Transfer and Chemical Reaction Steps in the Photodegradation Process," J. Photochem. Photobiol. A-Chem., 177, 212-217 (2006).

21. Demeestere, K., Dewulf, J., and Van Langenhove, H., "Heterogeneous Photocatalysis as an Advanced Oxidation Process for the Abatement of Chlorinated, Monocyclic Aromatic and Sulfurous Volatile Organic Compounds in Air: State of the Art," Crit. Rev. Environ. Sci. Technol., 37, 489-538 (2007).

22. Devahasdin, S., Fan, C., Li, Jr. K., and Chen, D. H., " $\mathrm{TiO}_{2}$ Photocatalytic Oxidation of Nitric Oxide: Transient Behavior and Reaction Kinetics," J. Photochem. Photobiol. A-Chem., 156, 161-170 (2003).

23. Yu, Q. L., and Brouwers, H. J. H., "Indoor Air Purification using Heterogeneous Photocatalytic Oxidation. Part I: Experimental Study," Appl. Catal. B: Environ., 92, 454-461 (2009).

24. Sleiman, M., Conchon, P., Ferronato, C., and Chovelon, J.-M., "Photocatalytic Oxidation of Toluene at Indoor Air Levels (Ppbv): Towards a Better Assessment of Conversion, Reaction Intermediates and Mineralization," Appl. Catal. B: Environ., 86, 159-165 (2009).

25. Zhao, W., Dai, J., Liu, F., Bao, J., Wang, Y., Yang, Y., Yang, Y., and Zhao, D., "Photocatalytic Oxidation of Indoor Toluene: Process Risk Analysis and Influence of Relative Humidity, Photocatalysts, and VUV Irradiation," Sci. Total Environ., 438, 201-209 (2012).

26. Jeong, J., Sekiguchi, K., Lee, W., and Sakamoto, K., "Photodecomposition of Gaseous Volatile Organic Compounds (Vocs) using $\mathrm{TiO}_{2}$ Photoirradiated by an Ozone-producing UV Lamp: Decomposition Characteristics, Identification of By-products and Water-soluble Organic Intermediates," J. Photochem. Photobiol. A-Chem., 169, 279-287 (2005). 